GEOLOGICAL SURVEY CIRCULAR 845

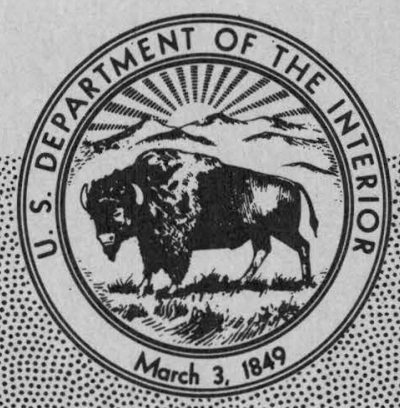

U.S. Geological Survey Workshop on Nonfuel Mineral-Resource Appraisal of Wilderness and CUSMAP Areas 



\section{U.S. Geological Survey Workshop on}

Nonfuel Mineral-Resource Appraisal of Wilderness and CUSMAP Areas

Compiled by Daniel R. Shawe

GEOLOGICAL SURVEY CIRCULAR 845

A general approach to appraisal of mineral resources in CUSMAP 1:250,000-scale quadrangles and in wilderness areas

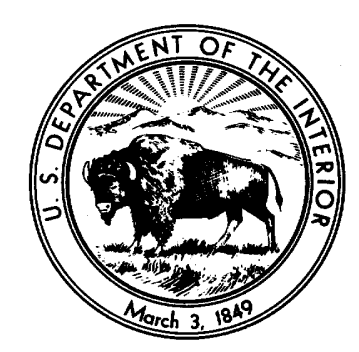




\section{United States Department of the Interior}

JAMES G. WATT, Secretary

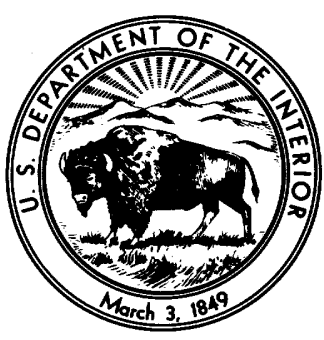

\section{Geological Survey}

Doyle G. Frederick, Acting Director 


\section{CONTENTS}

Page

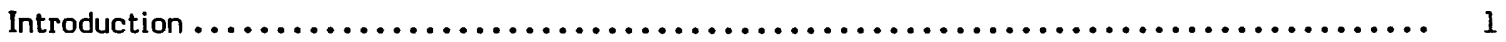

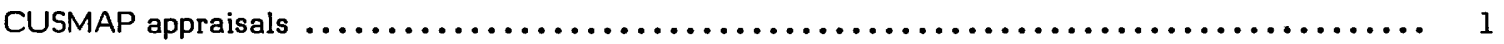

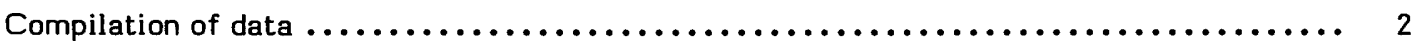

Ore-deposit modeling $. \ldots \ldots \ldots \ldots \ldots \ldots \ldots \ldots \ldots \ldots \ldots \ldots \ldots \ldots \ldots \ldots \ldots \ldots \ldots \ldots \ldots, 2$

First-stage analysis............................................ 4

Field studies to acquire needed data $\ldots \ldots \ldots \ldots \ldots \ldots \ldots \ldots \ldots \ldots \ldots \ldots \ldots \ldots \ldots \ldots, 4$

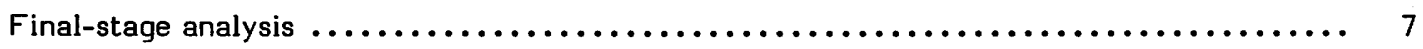

Presentation of resource appraisals and supporting data $\ldots \ldots \ldots \ldots \ldots \ldots \ldots \ldots \ldots \ldots .9$

Wilderness area appraisals $\ldots \ldots \ldots \ldots \ldots \ldots \ldots \ldots \ldots \ldots \ldots \ldots \ldots \ldots \ldots \ldots \ldots \ldots \ldots \ldots \ldots \ldots, 11$

Summary. ................................................ 13

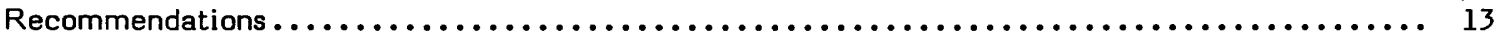

Appendix A, Organizing committee $\ldots \ldots \ldots \ldots \ldots \ldots \ldots \ldots \ldots \ldots \ldots \ldots \ldots \ldots \ldots \ldots \ldots \ldots \ldots$

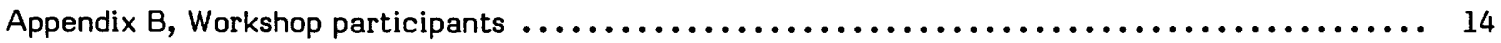

Appendix C, Speakers .......................................... 16

\section{ILLUSTRATIONS}

FIGURE 1. Interpretive maps showing favorableness of Bonneterre Formation in the Poplar Bluff quadrangle............................... 10

2. Diagram showing method of estimating amount of metal for a specific

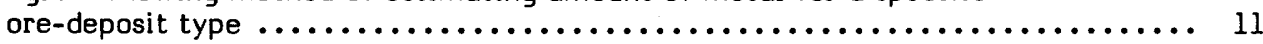

3. Diagram comparing tonnages of known deposits and undiscovered deposits $\ldots \ldots \ldots .11$

4. Analytical steps to present mineral-resource ratings $\ldots \ldots \ldots \ldots \ldots \ldots \ldots \ldots \ldots \ldots \ldots$ 



\title{
U.S. Geological Survey Workshop on Nonfuel Mineral- Resource Appraisal of Wilderness and CUSMAP Areas
}

\author{
Compiled by Daniel R. Shawe
}

\section{INTRODUCTION}

The Organic Act that established the U.S. Geological Survey in 1879 charges the Survey with responsibility to classify the public lands and to examine the mineral resources of the national domain. Numerous subsequent laws have added specific impetus to that general mandate. The Wilderness Act of 1964 directs the U.S. Geological Survey and the U.S. Bureau of Mines to make mineral surveys of wilderness and primitive areas within the United States by 1984. The Mining and Minerals Policy Act of 1970 requires that the U.S. Geological Survey foster and encourage private enterprise by providing information that will aid the development of mineral resources. The Alaska Native Claims Settlement Act of 1971 authorizes withdrawal and classification of large tracts of land in the State, called "National Interest Lands" or "d-2" lands, by 1978. As a result of the 1971 act, the U.S. Geological Survey initiated its Alaska Mineral Resource Assessment Program (AMRAP) to study $1: 250,000$-scale topographic quadrangles in the State. The Conterminous United States Mineral Assessment Program (CUSMAP), patterned after AMRAP, has the objective of assessing the mineral-resource potential of the adjacent 48 States, and is responsive to the legal requirements of Congressional acts cited as well as of other acts.

The U.S. Geological Survey has been conducting mineral-resource appraisals for different purposes and at different scales for many years, and its methods are constantly evolving. A workshop organized by the U.S. Geological Survey for the purpose of improving its appraisal of mineral resources in wilderness areas and CUSMAP quadrangles was held in Denver, Colo., December 10-12, 1979. Organizing committee members are listed in Appendix A. Participants, listed in Appendix B, included 34 members of the U.S. Geological Survey from Denver, Colo., Reston, Va., Menlo Park, Calif., and Salt Lake City, Utah; 11 representatives of the North American mining industry; six people from United States universities; four members of the Geological Survey of Canada; and one representative each from the U.S. Forest Service, the U.S.
Bureau of Land Management, the Colorado State Geological Survey, the Library of Congress, and the Colorado Mountain Club (an environmental group).

The first day of the workshop consisted of talks by specialists on some of the most significant purposes and some of the essential mechanics of resource appraisal. Names of speakers and titles and brief summaries of talks are given in Appendix C. During the second day, six working groups met separately to plan the steps needed to appraise mineral resources in one CUSMAP quadrangle and one wilderness area in each of three major geologic provinces of the United States. The $1^{0} \times 2^{0}(1: 250,000)$ topographic quadrangles selected were: Tonopah, Nev., in the BasinRange province; Poplar Bluff, Missouri-Arkansas, in the mid-continent region; and Hibbing, Minn., in the upper Midwest. All have major resource potential, but they are not now CUSMAP projects. Two working groups independently planned appraisals of a quadrangle and a wilderness area $(1: 50,000)$ within that quadrangle. Names of the working-group leaders and participants are indicated in Appendix B. Group leaders presented oral summaries of the results of each working group on the morning of the third day. Those summaries, later submitted as written reports, are compiled in this report into a recommendation for a general approach to appraisal of mineral resources in CUSMAP quadrangles and wilderness areas.

\section{CUSMAP APPRAISALS}

CUSMAP projects, designed to assess mineralresource potential of $1: 250,000$-scale quadrangles, generally are planned for a duration of 3-5 years and may take as much as 20 man years of work to complete. The project leader should be an experienced economic geologist familiar with the geology of the region in and around the CUSMAP quadrangle. The multidisciplinary project team is composed of field and mineral resource geologists, geophysicists, geochemists, and geostatisticians and assistants and is aided, as needed, by specialists in isotope geology, remote sensing, and paleontology. Normal field operations may be supplemented by extensive use of 
helicopters to facilitate geologic mapping and geochemical sampling.

The mineral-resource appraisals to date primarily are of metallic mineral commodities, including uranium and some high-unit-value nonmetallic commodities such as barite and fluorspar. Oil, gas, coal, and other nonmetallic resources are included in the appraisals, but were not discussed in this workshop.

All the working groups established generally similar procedures for making mineral-resource appraisals of $1^{\circ} \times 2^{\circ}(1: 250,000)$ quadrangles, regardless of geologic province. The most complete and most systematic methods involved these steps:

1. Compile data currently available.

2. Model possible ore deposits: identify and define the geologic environments that might be present that are favorable for the occurrence of ore deposits.

3. Prepare a first analysis of the available data.

4. Gather data through field studies in parts of the quadrangle where information is inadequate for resource appraisal.

5. Prepare a "final" analysis of the data.

6. Present the data in the form of finished products such as maps, diagrams, and texts that convey conclusions as to the mineral-resource potential of the quadrangle.

Because of time constraints, steps 1-4 may have to be carried out in part concurrently; the interplay of these operations carried out together, may in fact, offer some advantages. Of course, some planning and data compilation always will precede fieldwork when time permits.

\section{Compilation of Data}

Prior to fieldwork in the quadrangle, available factual data (from published literature and unpublished open sources), as well as subjective information obtained from knowledgeable individuals familiar with the quadrangle, are collected and compiled at scales of $1: 125,000$ and $1: 250,000$, as appropriate. Data that can be advantageously so treated are prepared for computer storage for possible later manipulation.

Classes of data that should be acquired are:

Geologic data

Geochronologic data

Geochemical data

Geophysical data, including magnetic data, gravity data, and radiometric data

Rock-alteration data

Landsat and other image data

Water and oil well drill data

Mines and mine production, prospects, and mining claims information

Details regarding the kinds of data to be acquired in these classes are given later in this report in the section that describes field studies.

\section{Ore-Deposit Modeling}

After collection of available data, mineralresource appraisal requires preparation of models of ore deposits that are likely to occur in the CUSMAP quadrangle being evaluated. Ultimately, ore-deposit modeling (description of ore deposits and definition of their geologic environments) should be a routine function of geologists in the Office of Mineral Resources of the U.S. Geological Survey, in which geologists other than those assigned to a CUSMAP project, particularly commodity geologists, should participate. Experience in the mining industry indicates that a useful ore-deposit model for exploration generally can be developed in 6 man months of literature search, mine visits, and interviews with experts, although some models are still only imperfectly developed, information on them is difficult to obtain, and probably years of work remain to be done on them. Models should be available at the onset of any CUSMAP project, and these models need only be "fine tuned" on the basis of data newly acquired in the CUSMAP quadrangle.

Ore-deposit models are developed from information in published literature and from knowledge geologists have gained from experience in mines throughout the world. The models are descriptive of the three-dimensional setting (geology) of the deposits, and they may describe habitat and process of formation (genesis) of the deposits. This geneticgeologic concept of ore-deposit modeling permits a clear separation of factual data and inference.

The models are thus descriptive dimensioned generalizations of the ore-deposit types that are likely to occur in any CUSMAP quadrangle. They include information on grade, tonnage, chemistry, and mineralogy of the ore deposits, as well as chemistry, physical properties, lithologies, and alteration haloes of the rocks that surround the ore deposits. The models include descriptions of geologic, geochemical, and geophysical signatures associated with ore-deposit types, and they emphasize the regional environment of the typical deposit. The most useful characteristics of ore-deposit models are those that are general and not dependent upon detailed investigations and, hence, are more readily determined during regional mineralresource appraisals. Genetic concepts can be built into the models when lack of facts prevents the construction. of a complete picture of the geologic environment of the modeled ore deposits.

Consideration should be given to all possible oredeposit types that occur in the United States and throughout the world. With this broad view in mind, the first and largest effort should go into establishing models of ore-deposit types known to occur within and near the quadrangle. These deposit types, because they are known, likely have been searched for in the quadrangle; other possible ore-deposit types also should be evaluated carefully. The tables of oredeposit types for the three quadrangles considered in this study, presented below, are not exhaustive, but they serve to show the variety, and variations from region to region, of deposits to be modeled.

\footnotetext{
Ore-Deposit Types, Tonopah Quadrangle Major

Porphyry molybdenum-copper (Hall deposit)

Arsenical gold

Stockwork (in Tertiary rhyolite, Round Mountain;

in Cambrian argillite-quartzite, Manhattan)

Disseminated (Northumberland)

"Epithermal" silver-gold (Tonopah)
} 
Magnesium (Gabbs)

Bedded sedimentary barite (East Northumberland Minor Canyon)

Gold-silver placers

Tungsten skarns

Tungsten veins

Magnetite skarns

Mercury veins

In granite

In volcanics

Antimony veins

Lithium-boron brines and associated hectorite clay

Lead-zinc replacements in carbonate

Base-metal sulfides with gold and silver in veins

Fluorspar veins and breccia pipes

Metal-bearing organic shales (Devonian)

Volcanogenic massive sulfide (Devonian)

Nickel-chromium-cobalt serpentinites

Tertiary lacustrine uranium (Siebert Tuff)

Uranium deposits associated with igneous rocks

Tin-titanium-vanadium placers

Some of the deposit types listed as minor, such as volcanogenic massive sulfide deposits and metalbearing organic shales of Devonian age, and lithiumboron brines and associated hectorite clays, may with further development become of major importance.

\section{Ore-Deposit Types, Poplar Bluff Quadrangle}

Major

Lead deposits that also contain zinc, copper, cobalt, nickel, and silver in the Cambrian Bonneterre Formation Minor

Iron-copper deposits in Precambrian rocks

Zinc-lead deposits in Ordovician rocks

Barite vein and replacement deposits in Paleozoic formations

Manganese deposits in Precambrian rocks

Tin deposits in Precambrian granites

Copper-lead-zinc massive sulfide deposits in Precambrian rocks

Bauxite or nickel-laterite deposits associated with buried weathered intrusives

Fluorspar and carbonatite deposits associated with buried syenite intrusives or cryptovolcanic centers, including fluorspar veins and mantos of Kentucky-Illinois type

Manganese and iron deposits in weathered surface rocks

Texas coastal-plain type uranium deposits in Tertiary sedimentary rocks of the Mississippi embayment

Copper-cobalt-nickel deposits associated with Precambrian ultramafic rocks

$$
\text { Ore-Deposit Types, Hibbing Quadrangle }
$$

Major

Volcanogenic massive sulfide deposits in greenstone belts

Magmatic copper-nickel deposits that also contain platinum, palladium, and cobalt in Duluth Complex
Archean gold deposits

Biwabik Iron-formation

Cretaceous unconformity-related uranium deposits

Cretaceous unconformity-related iron deposits

Sandstone-type uránium-gold deposits in Pokegama Quartzite

Sandstone-type lead-copper deposits in Pokegama Quartzite

Shale-hosted stratiform lead-zinc deposits in Virginia Argillite

Minor

Sedimentary manganese deposits

Carbonatites-kimberlites

Porphyry copper-molybdenum deposits

Accessory platinum, vanadium, and titanium in fossil placers

Archean nickel- and copper-bearing serpentinites

Silver veins (for example, Silver Islet type)

Ore-deposit models in the Tonopah quadrangle.The geologic settings of the Hall porphyry molybdenum-copper deposit and the Tonopah "epithermal" silver-gold district in the Tonopah quadrangle are described to show some aspects of ore-deposit modeling. The descriptions are by no means complete and are not adequate for mineral-resource appraisal.

Hall porphyry molybdenum-copper deposit:

1. The deposit is at and near the contact of a Cretaceous quartz monzonite-alaskite stock intruded into metamorphosed Permian clastic strata.

2. A large volume of Tertiary volcanic rocks lies east of the Hall deposit.

3. The deposit lies in a large zone of hydrothermally altered rocks.

4. Within a mile north and south of the deposit are small quartz veins that have produced minor silver and gold.

5. The deposit lies on the northwest flank of a large positive magnetic anomaly.

6. The deposit has not been dated but it may be no older than middle Tertiary.

7. The deposit is a large stockwork that contains on the order of 150,000,000 tons of rock grading $0.125 \mathrm{MoS}_{2} ; 40,000,000$ tons of rock grading 0.4 percent $\mathrm{Cu}$ also is present.

Deposits of the Tonopah district:

1. Ore deposits of the district are dominantly in hydrothermally altered andesites and dacites of the Miocene Mizpah Trachyte.

2. The deposits are surrounded by a large zoned halo of hydrothermally altered rocks.

3. The ore deposits are quartz veins that contain adularia, albite, barite, sericite, and other gangue minerals, and abundant chalcopyrite, galena, and sphalerite, together with silver minerals argentite, polybasite, pyrargyrite, and electrum, and minor native gold. Supergene ore minerals also are present.

4. The productive zone is a broad, concave-downward, saucerlike form, nearly $3 \mathrm{mi}(5 \mathrm{~km})$ across, centered on the core of the district.

5. Light-stable isotope studies suggest deposition of ore and ganque minerals from moderate- 
temperature ground waters circulated by heat from a buried stock beneath the core of the district.

6. Mineralization took place about 18-19 m.y. ago.

7. The district lies on the southeast flank of a large positive magnetic anomaly.

8. The district, now essentially inactive, has produced about 175,000,000 ounces of silver and 2,000,000 ounces of gold, together with minor lead and copper.

The geologic environment of the Tonopah district suggests that the large hydrothermally mineralized system of quartz veins and altered rocks may be a halo above a buried stock beneath the core of the district. The stock may be surrounded by a large porphyry (molybdenum-copper?) deposit.

The Hall deposit, prior to erosion of volcanic rock mantle, may have been capped by a system of silver- and gold-bearing quartz veins similar to that at Tonopah, assuming that the deposit is as young as Miocene.

Ore-deposit models in the Poplar Bluff quadrangle.-A skeletonized summary of the significant features of lead deposits of the southeast-Missouri type that likely are the major resource potential in the Poplar Bluff quadrangle provides a framework for deposit modeling.

Major or requisite criteria:

1. The deposits are in the Cambrian Bonneterre Formation.

2. The ore tends to be associated with Precambrian highs that were islands in the Late Cambrian sea.

3. The ore occurs within certain facies of the carbonate formation:

a. Near the limestone-dolomite interface and always on the dolomite side of the interface.

b. Generally in a belt of "brown rock" that surrounds the St. Francois Mountains (Precambrian high) like a collar.

4. The ore deposits are large (as much as $100 \mathrm{ft}$ or 30 $\mathrm{m}$ thick, $500 \mathrm{ft}$ or $150 \mathrm{~m}$ wide, and $5,000 \mathrm{ft}$ or $1500 \mathrm{~m}$ long--one is as long as $5 \mathrm{mi}$ or $8 \mathrm{~km}$ ); individual deposits may contain as much as $50,000,000$ tons of ore, grading about 3-10 percent $\mathrm{Pb}, 0.2-3.5$ percent $\mathrm{Zn}$, and a few tenths percent $\mathrm{Cu}$; they contain also cobalt, nickel, and silver.

Minor or permissive criteria:

1. Pinchout of the underlying Lamotte Sandstone suggesting proximity to a buried Precambrian high.

2. Presence of major faults, known mineralization, favorable trace-element geochemistry, Davis Formation overlying the Bonneterre, algal reefs, solution collapse structures.

\section{First-Stage Analyais}

Following collection of available data and development of ore-deposit models, the next step in resource appraisal is to make a first-stage evaluation of mineral-resource potential in those parts of the CUSMAP quadrangle for which data are more or less complete and of high quality (admittedly subjective evaluations). No attempt should be made to estimate potential of areas in the quadrangle for which data are incomplete or of poor quality. The purpose of the initial analysis is to identify deposit types and mineralizing episodes likely in the quadrangle and to form working hypotheses that will be tested and modified by subsequently acquired data for application to the "final" resource appraisal. Study areas and topical problems specific to the quadrangle will be identified for which additional data are needed to complete the evaluation. The general deposit models already established can at this stage be modified to better fit local conditions on the basis of data from mines and prospects in and adjacent to the quadrangle.

Several preliminary interpretive maps should be prepared prior to the field-data collection phase. The types of maps compiled depend partly upon the geologic province being dealt with; some of the maps are described as follows.

1. Maps showing post-mineral cover for each period of mineralization and deposit type believed to occur in the quadrangle. As familiarity is gained with the quadrangle, areas of shallow post-mineral cover should be distinguished. This set of maps will ultimately show those areas that are permissive for deposits of a specific type within a few thousand feet (say, 5,000 ft or $1500 \mathrm{~m}$ ) of the surface.

2. Tectonic-lithologic terrane maps that show those parts of the quadrangle that have behaved as a unit--perhaps even as a metallogenetic unit or "metallotect"--through geologic time. In the Tonopah quadrangle, such metallogenetic units might include the eugeosynclinal lithofacies of the Roberts Mountains allochthon, major strands of the Walker Lane strike-slip fault system, and Tertiary calderas. In the Poplar Bluff quadrangle, the most useful maps would be subsurface maps, and they might include topography of the buried Precambrian surface, isopach of the Lamotte Sandstone, and lithofacies of the ore-hosting Bonneterre Formation. In the Hibbing quadrangle, such metallogenetic units might include the Archean Ely Greenstone and the Lake Vermilion Formation, the Proterozoic $X$ Biwabik Iron-formation, and the Proterozoic $Y$ Duluth Complex.

3. Map showing ages, compositions, and tectonic types of intrusive rocks.

\section{Field Studies to Acquire Needed Data}

Using the working hypotheses developed in the first-stage analysis, together with the ore-deposit models developed for the quadrangle, the CUSMAP team identifies the kinds of data needed to solve specific problems and develops the strategy to acquire the data. Discussion of each of the major data categories, with variations dictated by the geologic settings of the CUSMAP quadrangles, follows.

GEOLOGIC DATA presented in the form of a geologic map generally provide the most fundamental information used in resource appraisal. Significance of surface data varies substantially among geologic provinces, however. In extremely complex geologic terranes such as the Basin-Range province, exemplified by the Tonopah quadrangle, elements of virtually 
all lithologic units known to be ore bearing are exposed in places at the surface and a geologic map is essential to define both the surface and subsurface distribution of ore-bearing units. In the Hibbing quadrangle in the upper Midwest, known ore-bearing units lie near the surface but are widely covered by thin glacial drift and outwash. Geologic mapping at the surface is not adequate to define the distribution of the ore-bearing units, and geophysical and geochemical surveys (as described later) can be applied to construct an adequate geologic map. In the Poplar Bluff quadrangle in the United States midcontinent region, rock units that are ore bearing to the north in the Rolla quadrangle are present in the deep subsurface. Their character, position, and mineral potential must be determined not by geologic mapping but by geophysical surveys, drilling, and regional stratigraphic and geochemical study of subsurface materials.

Geologic mapping, generally at a scale no larger than 1:50,000, should be designed to look for and to identify "geological metallotects" or regional geological structures or lithofacies supposed or known to be favorable for the occurrence of ore deposits. The mapping thus is guided by the ore-deposit models already established (both in fact and in concept). In the Tonopah quadrangle, examples of such metallotects are the Walker Lane zone of northwest-trending strike-slip faults (structurally controlled epigenetic metal deposits), the eugeosynclinal facies of marine Paleozoic rocks in the upper plate of the Roberts Mountains thrust system (gold, mercury, and barite deposits of "source-bed" origin), and certain Tertiary volcanic assemblages ("epithermal" gold and silver deposits). In the Poplar Bluff quadrangle, examples are Tertiary sedimentary deposits of the Mississippi embayment (Texas coastal-plain type uranium deposits), and southwest-striking faults of the New Madrid fault zone (Illinois-Kentucky type fluorspar deposits). Although much of the Poplar Bluff quadrangle has not been mapped at large scales, the surficial deposits are generally so thick and so widespread that additional mapping at the surface would provide little or no insight into the subsurface character and structure of the base-metal ore-bearing units. In the Hibbing quadrangle, examples are the Ely Greenstone and Lake Vermilion Formation (volcanic massive sulfide deposits), Biwabik Iron-formation (Proterozoic banded iron-formation deposits), and the Duluth Complex (magmatic copper-nickel deposits).

GEOCHRONOLOGIC DATA on the ages of rocks and minerals in CUSMAP quadrangles may be essential to the construction of ore-deposit models and to mineral-resource appraisal. Where the ages of sedimentary rocks are inadequately known, paleontologic information should be sought. Dating of some sedimentary units may be possible by determining isotopic ages of interlayered volcanic materials. Determinations of ages of metamorphic minerals may provide valuable data for interpretation of geologic (thermal) history and of the settings of mineral deposits. Isotopic age data on igneous rocks, which are commonly genetically related to ore deposits, and on minerals of the deposits themselves, are invaluable for constructing many ore-deposit models.
GEOCHEMICAL DATA are an essential part of the ore-deposit model and of the resource appraisal. The distribution and abundance patterns of suites of elements in relation to geoloqic parameters commonly are diagnostic for different types of ore deposits, their zonation, and their associated alteration halos. The presence of anomalously high amounts of metals in rocks may signal the proximity of a mineral deposit, or it may indicate "leakage" up through a hydrothermal system that contains mineral deposits at depth, or it may be unrelated to a mineral deposit. The geochemical "signature" of lithologic units may provide clues to geologic environments that are favorable for the occurrence of mineral deposits. Accurate geochemical data obtained from geologic formations which, because of their unusual character (for example, high organicmatter content), have not been characterized adequately geochemically in the past may reveal a resource previously overlooked.

Geochemical studies are planned in such a way as to provide data that are not already available, so that anticipated ore-deposit models for the quadrangle can be evaluated. Samples commonly are collected of stream sediments and of the B soil horizon in glaciated terranes throughout an area to provide geochemical data used to identify zones of metal concentrations. Metal concentrations thus found may indicate a favorable environment for ore deposits that otherwise may have been overlooked. But such surveys should not be carried out as though they were designed to identify ore-deposit targets. Further, the failure of streamsediment geochemistry to reveal metal anomalies at the surface cannot be used in a negative way to rule out the presence of favorable environments or of ore deposits. Samples of rocks provide geochemical data valuable for characterizing the geologic environment in which the rocks formed and hence can be used in ore-deposit modeling. Samples of hydrothermally altered rocks provide geochemical data that can be used to determine favorableness or unfavorableness of some geologic environments. Furthermore, bedrock geochemistry may reveal whether or not the rocks have been altered, as some altered rocks are not obvious to the naked eye.

Three types of geochemical surveys are appropriate for the Tonopah quadrangle. The first is a regional geochemical suryey with a density of one sample per $2 \mathrm{mi}^{2}\left(7 \mathrm{~km}^{2}\right)$ in areas not covered by Quaternary valley fill. Heavy-media splits and minus80-mesh fractions of stream-sediment samples should be analyzed by the six-step (33 elements) spectrographic method. The second type of survey is tailored to specific deposit types within areas favorable for those deposits. Sample density, element suite analyzed for, and method of collection and treatment of samples would be tailored to the deposit type, considering factors such as dimensions and form of the deposit and its possible alteration halo. Spectrographic analysis of these samples may not be desirable if secondary dispersion of elements in geochemical haloes is suspected. The third type of geochemical survey is for the purpose of determining the chemical character of lithologic units throughout the quadrangle. Depending upon the physical variation within lithologic units and the extent of their 
distribution, perhaps 5 to 25 samples would be required to characterize each unit. Six-step spectrographic analyses should provide adequate chemical data for the characterizations, and only in special cases should additional methods be required (for example, specific ion electrode to determine fluorine content).

Geochemical sampling of surficial materials (rock, stream sediment, soil) in the Poplar Bluff quadrangle would not be useful in the search for Viburnumtype lead deposits because the ore-hosting Bonneterre Formation is deeply buried. On the other hand, if drill-hole samples of the buried formations become available, geochemical studies would be of great value in characterizing possible favorable geologic environments for ore deposits. The inadequacy of any surface methods, geologic or geochemical, in characterizing geologic environments of the buried rocks emphasizes the necessity of acquiring drill-hole samples for study. Geochemical surface sampling would be useful to test the potential for coastal-plain-type uranium deposits and Kentucky-Illinois-type fluorspar deposits in the southeast part of the quadrangle. Elsewhere in the quadrangle, surface sampling would probably reveal zinc anomalies in Ordovician rocks, but the known zinc deposits of northern Arkansas are small and uneconomic. Also, the possibility that unrecognized types of deposits miaht occur close to the surface suggests that some surface geochemical surveys may be warranted.

In the Hibbing quadrangle, geochemical surveys of surface materials should be carried out in areas that may contain mineral deposits but where favorable environments were not recognized in the past. The entire quadrangle thus need not be covered. Sample stations should be about $2 \mathrm{mi}(3 \mathrm{~km})$ apart, and soil sampling of the $B$ horizon is recommended. In addition, geochemical surveys of some bedrock lithologic units should be made, as for example the Archean iron-formations, to locate zones of anomalously high gold content that may indicate the presence of gold ore deposits. Auger drilling through glacial debris may be required to collect samples in some areas.

GEOPHYSICAL DATA, including magnetic, gravity, and radiometric, are needed for mineralresource appraisal in almost all areas. Other geophysical data such as rock magnetization and density, seismic, electromagnetic, electrical resistivity, and audio-magnetotelluric are valuable in special areas, but will not be discussed further here.

MAGENTIC DATA, commonly obtained by airborne surveys, are useful to infer subsurface distribution of lithologic units as well as to pinpoint certain anomalies related to mineral deposits. The data also may provide insight into regional structural framework.

An airborne magnetic survey in the Tonopah quadrangle should be flown at a line spacing of $1,500 \mathrm{ft}$ $(0.5 \mathrm{~km})$ and at a terrain clearance of $500-1,000 \mathrm{ft}$ $(150-300 \mathrm{~m})$. The aeromagnetic data can be used to detect possible unidentified or shallow, buried intrusive bodies, zones of sulfide-mineralized rocks, and highly magnetic rocks possibly related to mineral deposits. The magnetic map also may be used to project exposed geology into covered areas, and it may reveal discontinuities related to important structural zones. Aeromagnetic mapping of the Poplar Bluff quadrangle is important, as the data indicate depth to magnetic basement and thus could indicate highs on the buried Precambrian surface. Stratigraphic pinchouts against the Precambrian "highs" may have localized mineralized zones in buried Paleozoic formations. Aeromagnetic data $(3,000-\mathrm{ft}$ or $1-\mathrm{km}$ line spacing, 1,000-ft or $300-\mathrm{m}$ terrain clearance) that is available for the Hibbing quadrangle is necessary to aid identification of lithologic units where they are buried beneath glacial debris. These data also may provide information valuable for the definition of zones favorable for the occurrence of certain types of ore deposits. Some favorable areas in the Hibbing quadrangle may require further testing by aeromagnetic surveys at a line spacing of about $1,500 \mathrm{ft}(0.5 \mathrm{~km})$ and terrain clearance of $500 \mathrm{ft}(150 \mathrm{~m})$, and by ground electromagnetics, to improve understanding of the geologic environments in which ore might have been deposited.

GRAVIMETRIC DATA, obtained from ground stations, may aid interpretation of the subsurface distribution of rock units and may provide insight into regional structural framework.

In the Tonopah quadrangle, gravity profiles should be established using roughly half-mile (1-km) spacing on lines about $10 \mathrm{mi}(15 \mathrm{~km})$ apart, partly to define intermontane basins and pediment geometries, partly to define subsurface distribution of major rock units, and partly to refine interpretation of regional gravity data bearing on regional structures. Gravity data are considered less important for evaluation of mineral potential in the Poplar Bluff quadrangle. However, both gravity and aeromagnetic data are essential to an understanding of the New Madrid rift zone that extends across the southeast part of the quadrangle. Postulated buried basic to ultrabasic plutons along the margins of the rift may have played a role in genesis of mineral deposits in this and adjacent quadrangles. In the Hibbing quadrangle, gravity stations should be established throughout in a grid of 2-mi (3-km) spacing to provide data useful for interpreting the distribution of rock units beneath glacial debris. In addition, specific environments can be further evaluated; for example, the known gravity low in the Virginia Argillite should be evaluated further to establish presence or absence of a second-order sedimentary basin that has possible stratiform leadzinc potential.

RADIOMETRIC DATA, obtained by airborne surveys, generally are used to search for radioactivity anomalies related to deposits of radioactive minerals. The data should be applied more widely to define distribution of rock units of differing radioactivities (distinguished as to amounts of potassium, thorium, and uranium). These data then can be used to help establish the geologic occurrence of these rock units, and can be applied to ore-deposit modeling.

The distribution of hydrothermally altered rocks in any geologic terrane outlines zones through which mineralizing fluids have passed; mineral deposits may occur within these zones wherever favorable lithologic and structural environments existed for precipitation of ore minerals. In the arid West, as exemplified by 
the Tonopah quadrangle, the generally excellent exposure of bedrock allows ground mapping of hydrothermally altered rocks. Also, as will be discussed, certain aerial or satellite photography when used in this region may provide images from which zones of hydrothermally altered rocks can be interpreted.

LANDSAT images can be used to help determine regional structural elements that have influenced mineral distribution, such as lineaments, and that are not evident on available geologic maps or on largescale aerial photographs. Certain multispectral images obtained from satellite or aerial photography may reveal zones of altered rock (specifically, distribution of hydrated iron oxides) spatially associated with deposits in the Basin-Range province.

Even where surface geology is well known and where geophysical data aid projection of surface geology into the subsurface, geologic information obtained from water, oil, gas, and other drill holes can be of great value. Where surface units are flat and widespread, drill data may be indispensable to determine subsurface geology.

In the Tonopah quadrangle, almost no data are available from water, oil, or gas test wells. Some information can be obtained from test holes drilled in a few places by the U.S. Geological Survey during studies in the central Nevada Test Site in the 1960's. In general, information from mining industry drilling in the quadrangle is impossible to obtain because of company policy. However, drilling by the U.S. Geological Survey to test hypotheses of hitherto-unknown deposit types envisioned within the quadrangle, or to obtain geological information essential to ore-deposit modeling, is feasible and appropriate to reach the objectives of CUSMAP projects. Of course such drilling would be used to test for ore-deposit environments and to develop models for ore types and not to define or to test actual ore-deposit targets. In the Poplar Bluff quadrangle, some subsurface information may be available from water, oil, and gas drill holes; in general, mining industry drill-hole data are not available because of company policy. The U.S. Geological Survey should drill some deep holes to reach favorable ore-deposit horizons, particularly the Bonneterre Formation, host of the great lead deposits of the Viburnum trend farther north in Missouri, in order to acquire the geologic information necessary to make an adequate mineral-resource appraisal. Locally, in the Hibbing quadrangle, shallow drilling of overburden in order to sample bedrock for petrographic and geochemical studies, and to determine thickness of glacial drift, may be required. Some water well-log data on the character of the shallow subsurface are available for the Hibbing quadrangle.

Information on mines and mine production, prospects, and mineral occurrences is highly desirable, if not necessary, for any mineral-resource appraisal as such data form a factual basis for judging resource potential in favorable geologic environments where mineral deposits are not known. Data needed include details of the geologic setting of mined ore deposits and mineral deposits exposed in prospect workings, such as petrography, physical properties, and chemistry of host rocks, character of alteration haloes, structural controls, and grade, tonnage, chemistry, and mineralogy of the ore. Information on mining claims-their type and location--facilitates their later study and aids determination of the legal status of land in areas being evaluated for the possible use of natural resources.

Data on mines and mine production, prospects, and mining claims should be obtained throughout the CUSMAP quadrangle; where data from mines and prospects in the vicinity of the quadrangle can be useful in developing ore-deposit models for application in the quadrangle, these, too, should be collected.

\section{Final-Stage Analysis}

After newly acquired field and other data have been added to the previously compiled data on base maps at a scale of $1: 125,000$ or $1: 250,000$, then interpretation takes place in three steps.

1. Each map depicting a parameter (such as geologic or aeromagnetic) is examined for anomalies and other indications of environments favorable for ore deposits. For example, large magnetic anomalies are looked for on the aeromagnetic map, metal anomalies are determined on the geochemical maps, and lithologic and structural peculiarities are noted, or favorable geologic relations are outlined, on the geologic map.

2. An integrated interpretation is made of all the data bases wherein converging lines of evidence are used to define environments favorable for mineral deposits. Examples of types of useful evidence are magnetic features that are incompatible with the known rock units, weak geochemical anomalies that correlate with specific rock units, and certain geologic units that signal a specific mineral environment, such as fluorine-rich rhyolites with which might be associated uranium, fluorspar, or beryllium deposits.

3. The data base maps are given an integrated interpretation for each deposit type, as established in the ore-deposit modeling stage, to determine characteristics that may indicate that an area is permissive for that deposit type. Where indicators of geologic favorableness do not fit in the context of known oredeposit types, clues may be provided to previously unrecognized deposit types.

This subjective analysis is performed jointly by the data gatherers that form the CUSMAP team and the ore-deposit-model builders both on the CUSMAP project and throughout the Office of Mineral Resources of the U.S. Geological Survey, especially commodity geologists. The assessing team must spell out the reasoning behind its analysis so that users can understand the rationale of the evaluation. As shown later, the manner of presentation of the data in maps, tables, and texts can demonstrate rationality of analysis.

The subjective analyses of possible occurrences of certain ore-deposit types within a CUSMAP quadrangle can be refined beyond the assessment that an area is favorable for the occurrence of a particular deposit type. Such refinements permit fixing degrees of favorableness that can be presented in qualitative or possibly semiquantitative terms. The majority of participants in the Mineral-Resource Appraisal workshop, however, believed that quantitative estimates of 
mineral-resource potential are impossible and consequently are generally inadvisable to attempt. Nevertheless, among the participants there was a strongly held minority view of the validity of geostatistical evaluation of resources to produce quantitative values that have probability limits. But also there was a generally held belief, even among the statisticians, that adequate, accurate data of the right kind (objective data) are not available to permit rigorous statistical appraisals of potential resources. Furthermore, statistical estimates of mineral resources have never been adequately tested by production.

Favorableness can be described using three criteria: (1) likelihood (or degree of favorableness) that a deposit type is present; (2) size of the deposit or deposits (amount of commodity that may be available) if present; and (3) adequacy of the data on which the assessments are made. A simple numerical scale can be used to grade these categories. Thus, likelihood can be graded as a (1) high probability of containing deposits of the type, (2) probability of containing deposits of the type, and (3) low probability of containing deposits of the type. Some of the working groups believed that a fourth category indicating no probability is warranted. Size (or amount) can be graded as (1) large, (2) moderate, and (3) small. Known size and grade ranges of particular ore-deposit types should be used in making the significance classifications so that users will have a basis for judging the meaning of the size classifications indicated. Whether or not estimates of favorableness and amount of resources present are valid depends upon the quality of the data available for the assessments; hence, some indication of adequacy of the data should be given.
Because of differences in judgment, not everyone will agree that the available data are sufficient for mineral- resource appraisals at the $1: 250,000$ scale of the CUSMAP quadrangles. But a twofold classification, (1) adequate data, and (2) inadequate data, will at least inform the users of the appraisers' opinion of the sufficiency of the data.

Other factors that have a bearing on the importance of mineral-resource data generated by the U.S. Government are current accessibility of mineral deposits, their present and future economic certainty of production, their time lag to production, the desirability of the commodities for National strategic purposes, and the desirability of the commodities for National economic leverage. Assessments by the U.S. Government of these factors may not be meaningful to the private mining industry for exploration for and development of economic supplies of mineral commodities, but they are meaningful in respect to planning and decisions that the Government itself must make in the interests of National security and welfare.

In order to systematize the final-stage analysis of resource potential in the Tonopah quadrangle, the working group under $D$. R. Shawe set up a review procedure that could permit a certain quantification, albeit subjective, of the importance of assessed resources. The following table outlines the main elements of the review, using as an example the porphyry molybdenum-copper-deposit type. In this example the information supplied is in part imaginary and is furnished merely for demonstration purposes; classification numbers, where used (in parentheses), are those previously defined.

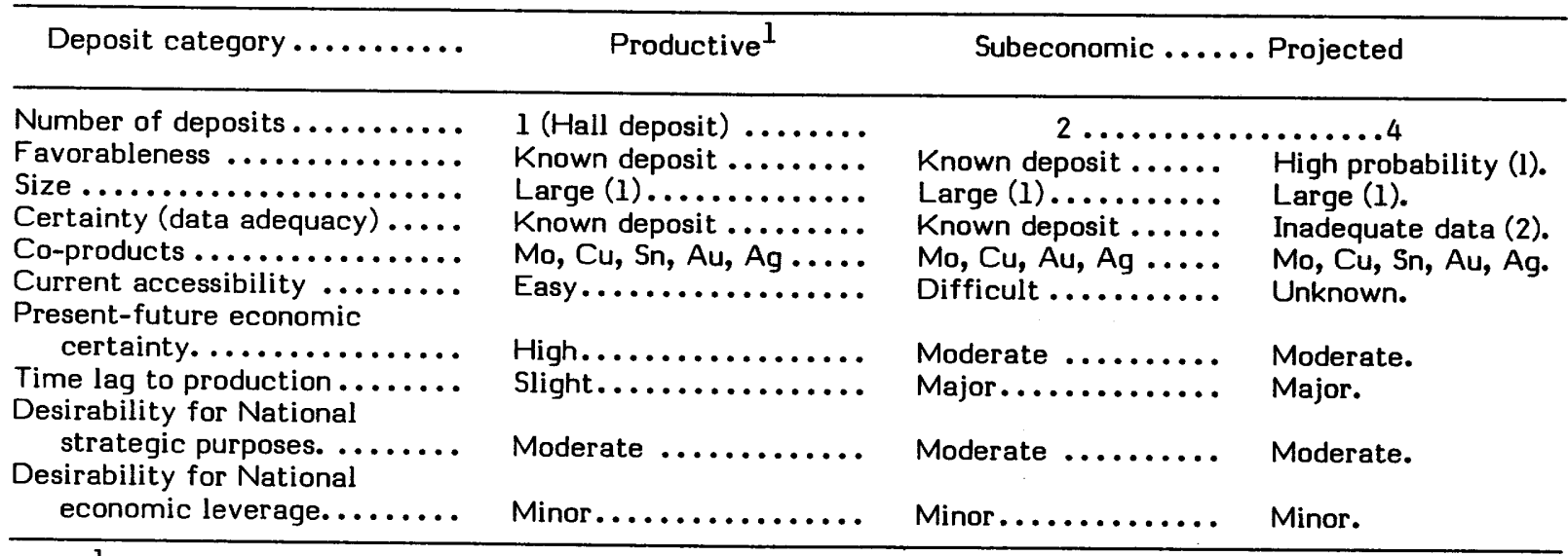

${ }^{1}$ Past or present production, or capability of current production.

The various classifications shown in the table can be weighted as to relative significance in order to arrive at a general value (importance) of the assessed resources. 
The majority of participants in the working groups concluded that statistical quantification of resource appraisals on the basis of available data generally is not warranted. However, the statistical treatment proposed by the Hibbing quadrangle working group under D. F. Sangster may be useful for certain geologic environments if properly qualified. ${ }^{1}$ For example, existing frequency-distribution curves of ore tonnages and copper grades in massive sulfide deposits could be combined with subjectively derived estimates of number of deposits in areas determined to be favorable for the occurrence of massive sulfide deposits. These probability curves could be combined by the Monte Carlo technique to produce a probability curve for tons of contained copper in deposits of the massive sulfide type. Other deposit types in specific lithologic-structural domains, or in favorable geologic environments (metallotects), might be treated similarly if available data seem adequate.

\section{Presentation of Resource Appraisals and Supporting Data}

Two distinct products for two completely different audiences should result from the CUSMAP studies. One should be a succinct summary that presents in as simple language as possible the major results of the resource analysis. The other is a technical product that presents as fully as possible the detailed data resulting from the field and office studies.

The first and more important product from the standpoint of National welfare should be an "executive summary" that is a succinct statement of the major results of the mineral-resource appraisal. Such a summary is already a part of the reports of wilderness investigations. This product is prepared for the use of nongeologists who are generally specialists in other government agencies, in the U.S. Congress, and in organizations outside the government that have mineral-resource interests. Because such users must understand clearly the message of this product, the report should be proofread by a college-trained nongeologist before it is presented to its users. The report should be short and should contain a simple message based on the needs of the ultimate users of the mineral-resource analysis. It must contain maps that clearly show areas of mineral potential and tables that describe what that mineral potential is. Maps used in the report should be simple and understandable to the public. The summary should list the commodities likely to occur and their amounts in as quantita-

${ }^{1}$ To properly qualify any resource estimate, which is a quantification of the unknown, it must be emphasized that a resource estimate cannot be used as an indication of amount of resources that ultimately will be produced. tive terms as is reasonable. Absolute numbers for a specific deposit type are not possible, but "order of magnitude" can be implied by comparisons to known typical sizes and grades of deposits of that type. The value of commodities relative to National requirements is an appropriate subject to be addressed in the executive summary. Reference can be made in the summary to strategic minerals as classified by the U.S. Bureau of Mines. The date of the mineral-resource appraisal should appear in the title of the executive summary report, to emphasize the fact that mineralresource appraisals are only interim assessments that should be updated periodically.

The second or technical product consists of text, tables, and all the data maps and interpretive maps, at a scale of $1: 250,000$, that have been produced in a CUSMAP study. Data maps needed for the CUSMAP technical report are of considerable number and variety. Most important are geologic maps, especially a primary colored geologic map of the quadrangle at a scale of $1: 250,000$. Additional geologic maps at the same scale might be appropriate, such as structural or tectonic maps, and "breakout" maps showing separate important geologic units. Geologic maps at a regional scale (perhaps $1: 1,000,000$ or even smaller scale) may be useful to show the relation of major metallotects to the CUSMAP quadrangle. Geophysical maps, where needed, show gravity, aeromagnetic, airborne radioactivity, and other types of geophysical data. Geochemical maps show stream-sediment sample geochemistry, rock geochemistry, and distribution of minor commodities, based on data such as that from spectrographic analyses of mineralized rocks from prospects and mines. Depending upon complexity, each geochemical map can show the distribution of one to several elements. In general, elements shown are metals; some nonmetals such as fluorine that may be useful "pathfinder" or guide elements should be shown. A map indicating distribution of hydrothermally altered rocks is of great value in some regions. A spot map gives distribution, size, and type of the known mineral deposits in the CUSMAP quadrangle. The known deposits should be distinguished as to those currently in production, those that are subeconomic, or those that are being prepared for but are not yet in production.

The data maps are used to produce interpretive maps that show the quadrangle divided into units of specific geologic environment and mineral potential. These units are then further defined into permissive areas in which rock assemblages of appropriate age that are favorable for specific ore deposit types occur within a reasonable distance (say, 5,000 $\mathrm{ft}$ or $1500 \mathrm{~m}$ ) of the surface. The permissive areas are then subdivided and classified into those prospective areas that contain positive indications of a mineral deposit or district of the type considered. Statements such as 
"there is an $X$-percent probability that $Y$ number of deposits (of a certain type) may occur in $Z$ area" are appropriate, if adequately supported. The prospective areas also may be classified as to high, medium, or low potential for specific deposit types, using the subjective-probability classification already described. Reasons for the classification should be stated clearly. Areas for which data are insufficient to indicate mineral-resource potential should be labeled clearly. A statistical (or even subjective) extrapolation of mineral-resource.potential into areas of shallow cover in which the quality of the available data is greatly reduced should be attempted, but the tentative nature of the data should be emphasized.

Interpretive maps accompanying the technical report are primarily to show distribution of areas favorable for the occurrence of mineral deposits. The favorableness maps show distribution of geologic environments of each of the important ore-deposit types in the quadrangle; the maps should indicate also the metal co-products, ranked by significance, because the commodities present have a bearing on favorableness classification. In some areas a spot map of known deposits can be incorporated with a favorableness map in order to indicate more clearly the reasons for the favorableness classification. Degrees of favorableness shown on the map are based on the three-criteria classification already described.

Some possible derivative maps, proposed by the working group under E. L. Ohle for the Poplar Bluff quadrangle and based both on available data and on interpretation, might show the subsurface distribution

\section{MODIFIED GEOLOGIC MAP}
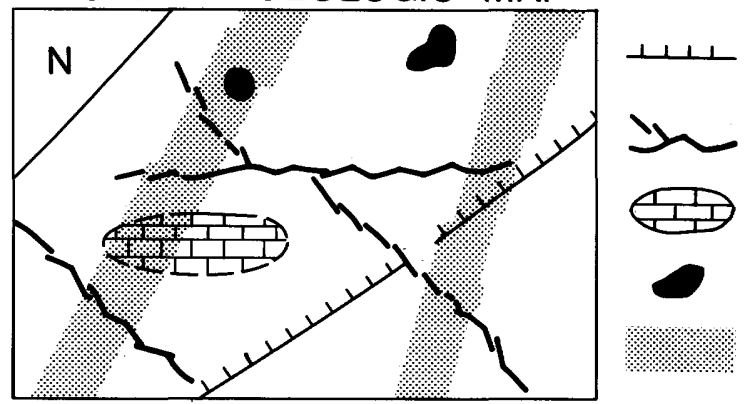
Bonneterre Formation (dolomite) is present northwest of this line

Major faults

Bonneterre is limestone

Buried Precambrian knobs (from aeromagnetic map)

Zones of abnormally high content of base metals in drill samples

$\mathrm{N}$ No subsurface information available
Criteria for mineral deposits

\begin{tabular}{l|l|l|l|l|l|l|l|l|l|l|} 
Criteria for mineral deposits & $\begin{array}{l}\text { Areas numbered on map } \\
\text { Bonneterre Formation }\end{array}$ & + & + & + & + & + & + & - & + & + \\
Dolomite & + & + & + & + & + & + & - & - & 0 \\
Buried Precambrian knobs & + & - & - & + & - & - & - & - & - \\
Major faults & + & + & - & - & + & - & + & - & 0 \\
Base metals & + & + & + & - & - & - & + & + & 0 \\
\hline
\end{tabular}

\section{EXPLANATION}

+ Listed criterion is present

- Listed criterion is absent

O Insufficient data to infer presence or absence
DISTRIBUTION OF

\section{FAVORABLE CRITERIA}

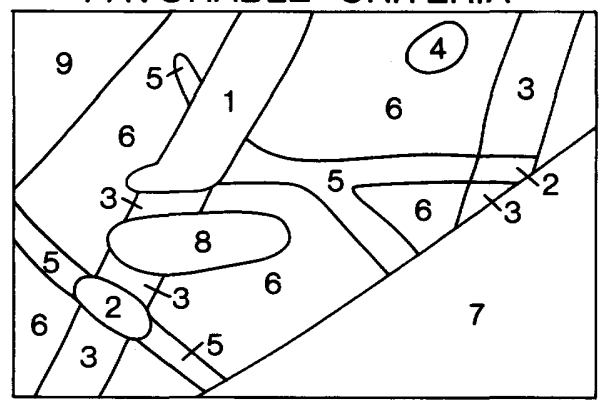

MAP OF MINERAL

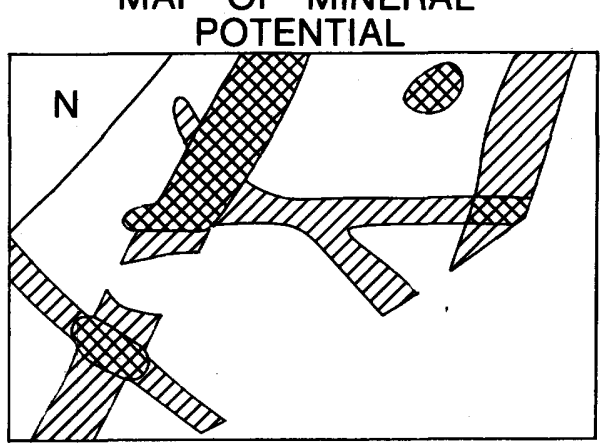

EXPLANATION

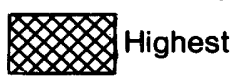

DDPHigh

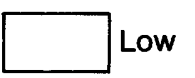

$\mathrm{N}$

Insufficient data

FIGURE 1.--Interpretive maps showing favorableness of the Bonneterre Formation for ore deposits of the Viburnum type in the Poplar Bluff quadrangle. 


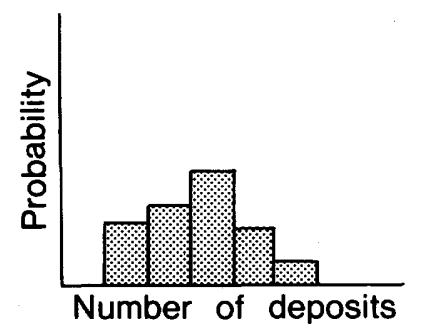

Determined by
subjective judgment
of "experts"

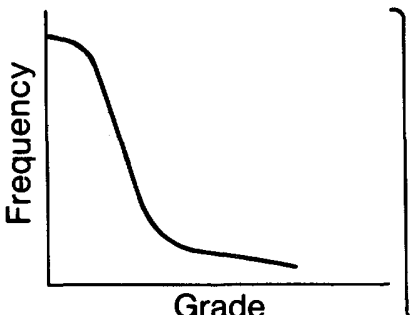

Tonnage-grade
model determined
from known deposits

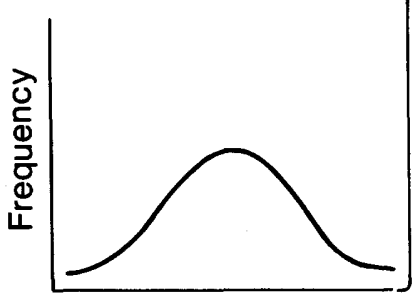

Tonnage

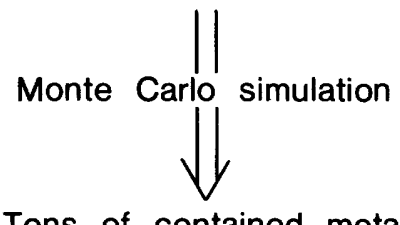

Tons of contained metal

FIGURE 2.--Diagram showing method of estimating amount of metal for a specific ore-deposit type within an area defined as geologically favorable.

of the Bonneterre Formation, topographic highs on the Precambrian surface, distribution of brown rock, and distribution of hydrothermally altered and mineralized rock. Using some of these same parameters, the working group under A. V. Heyl prepared an example of a set of partly imaginary interpretive maps showing favorableness of the Bonneterre Formation for ore deposits of the Viburnum type in the Poplar Bluff quadrangle, as shown in the accompanying illustration (fig. 1).

The Hibbing quadrangle working group under D. F. Sangster was the only one to propose in detail how favorable areas might be rated by subjective probability. This group suggested a summary display of information for nontechnical users. The accompanying diagram (fig. 2) shows the method of estimating amount of metal for a specific ore-deposit type within an area defined as geologically favorable. Tonnage of known deposits and estimated tonnage of

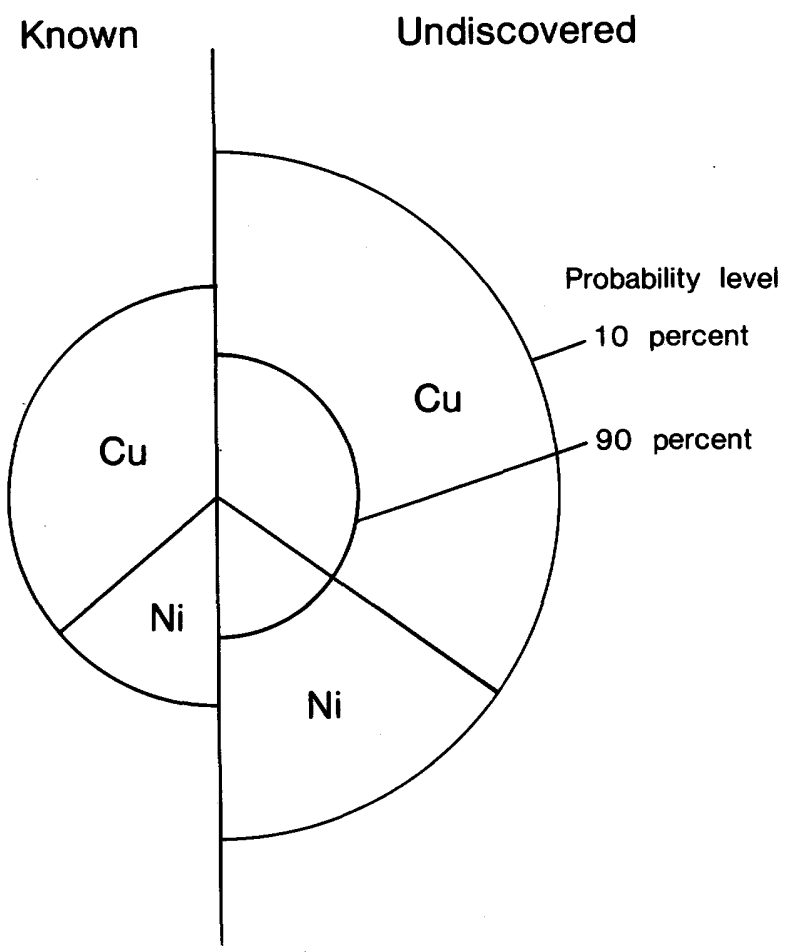

Tonnage proportional to area

FIGURE 3.--Diagram comparing tonnage of known deposits and estimated tonnage of undiscovered deposits.

undiscovered deposits (shown at the 10-percent and 90percent probability levels) are compared in a diagram (fig. 3). These diagrams then are included on the map showing favorableness for the deposit type(s) (fig. 4).

To complete the presentation of data, appropriate texts and tables, fitted to the function of the maps, should accompany both the data maps and the interpretive maps.

The technical product should include recommendations for further work to (1) improve the mineralresource appraisal, and (2) advance the science of geology based on additional geologic and other geoscientific observations within the quadrangle. An important final step of each CUSMAP project is to review critically the method used for mineral-resource analysis and to prepare a modified version for other CUSMAP studies that will follow. And again, the date of the mineral-resource appraisal should appear in the title of the technical report.

\section{WILDERNESS AREA APPRAISALS}

Wilderness area studies generally are planned for a duration of 1-3 years and may take more than 10 man years of work to complete. Project personnel require the same qualifications as do those of the CUSMAP projects. Wilderness mineral-resource 


\section{INFORMATION $\Longrightarrow$ ANALYSIS $\Longrightarrow$ PRESENTATION}

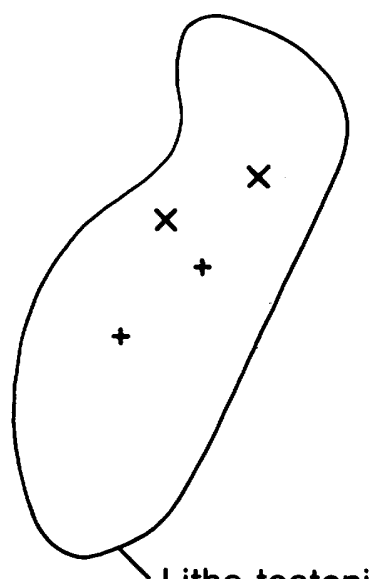

Litho-tectonic domain

+ Deposit-type A--metal $x$

$X$ Deposit-type B--metals y and $z$

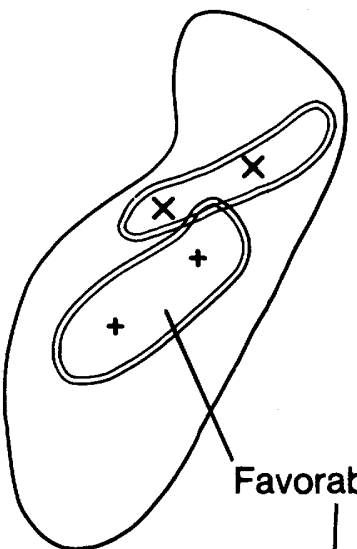

Favorable area

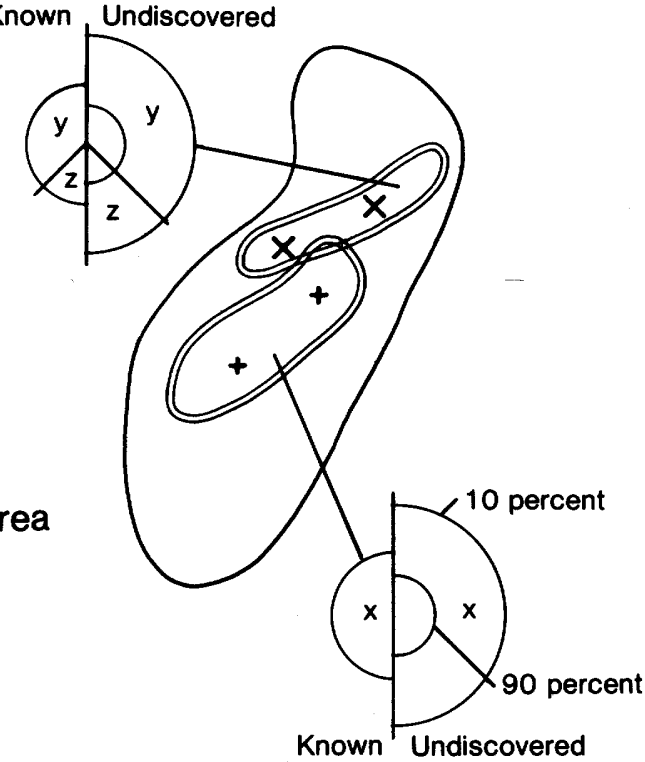

Deposit-type A

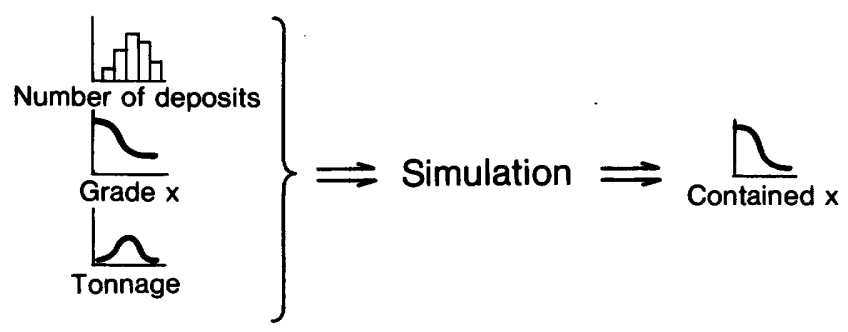

Deposit-type B

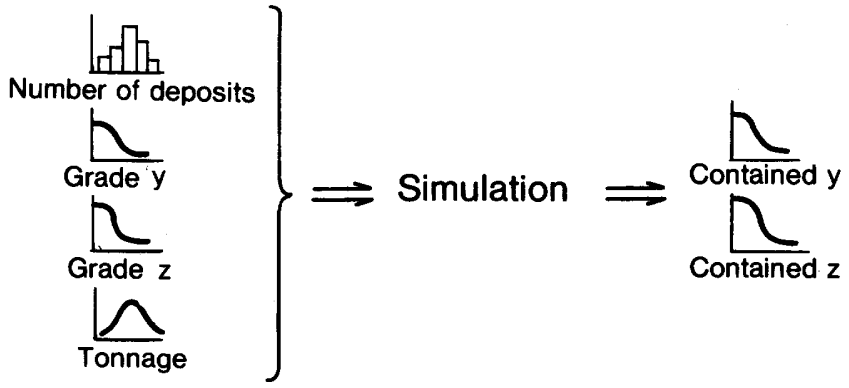

FIGURE 4.--Maps and diagrams showing analytical steps to present mineral-resource favorableness ratings. 
appraisals are similar to the CUSMAP appraisals and differ only in scale. ${ }^{2}$

The two working groups that evaluated the Tonopah quadrangle also considered procedures for mineral-resource appraisal of an area arbitrarily designated as the "North Reveille Wilderness" (not a real wilderness) in the northern Reveille Range. The area covers about 65,000 acres and is adjacent to the Reveille mining district to the southeast. Minor mineral occurrences and areas of hydrothermally altered rocks lie within the boundaries of the wilderness area. Adequate appraisal of the mineral-resource potential of the wilderness requires, in addition to. study of the area itself, study of some of the area surrounding it, particularly the Reveille mining district.

The two working groups that evaluated the Poplar Bluff quadrangle also considered procedures for mineral-resource appraisal in an area designated by the U.S. Forest Service as the Irish Wilderness. The Irish Wilderness, in the central part of the Poplar Bluff quadrangle, covers about 23,000 acres and has no known mineral deposits in or near it. The wilderness nevertheless is underlain by the Bonneterre Formation in an area that may be favorable for the occurrence of ore deposits of the Viburnum type. In order to appraise this possibility adequately, two methods of investigation seem necessary--an aeromagnetic survey to evaluate the possibility of a buried Precambrian high in the vicinity, and drilling several deep holes, perhaps as many as six, to determine the character of the Bonneterre Formation.

The two working groups that evaluated the Hibbing quadrangle also considered procedures for mineral-resource appraisal in an area hypothesized to represent a wilderness area. The "Chippewa Wilderness" (not a real wilderness) in the northwest corner of the Hibbing quadrangle covers about 110,000 acres and has no known mineral deposits in or near it, although similar geologic terranes elsewhere in the world may be richly mineralized. The wilderness area is almost wholly covered by glacial debris and the bedrock geology is poorly known. The almost total lack of geologic information prompted the working group under D. F. Sangster to propose the following steps that would help to complete a mineral-resource appraisal of the Chippewa Wilderness.

1. Obtain airborne total-field magnetic, airborne gradiometer, and airborne electromagnetic data at a line spacing of $1,500 \mathrm{ft}(0.5 \mathrm{~km})$ or $0.5 \mathrm{mi}$ $(800 \mathrm{~m})$.

2. Make a geological examination of whatever outcrops (probably few) can be found within the area.

3. Drill overburden by drills mounted on tracked vehicles to obtain samples of till. This work would be contingent upon obtaining permission from the U.S. Forest Service for access by tracked vehicles; if the work were done in winter

${ }^{2}$ Wilderness projects, by legislative mandate, are carried out in cooperation with the U.S. Bureau of Mines. The USBM examines records for claim and mine locations, tabulates reserves and past production, studies metallic and nonmetallic ores, and participates in determination of resource potential. when the ground and bodies of water are frozen and covered by snow, little if any damage to the terrain would occur. Drilling should begin along the existing roads that rim the area and the one road cutting through the middle of the area. Drilling to a depth of $200 \mathrm{ft}(60 \mathrm{~m})$ may be required in places.

4. Analyze till samples for standard elements; examine suboutcrop rock chips and heavymineral concentrates under the microscope. Failure to detect anomalously high amounts of valuable metals or minerals as a result of sampling and geochemical analysis cannot be construed as an indication of unfavorableness for mineral potential.

5. Compile data from studies 1-4 to produce geologic and geochemical maps; more detailed drilling and ground geophysical surveys to complete geologic, geochemical, and geophysical coverage might be required the following year.

6. Delineate on maps any favorable areas found.

\section{SUMMARY}

The U.S. Geological Survey workshop concluded that mineral-resource appraisals of CUSMAP quadrangles and wilderness areas should be undertaken in the following steps: (1) compile available data; (2) model possible ore-deposit types; (3) prepare a firststage analysis of the available data; (4) gather additional needed data through field studies; (5) prepare a final-stage analysis; and (6) present the data in the form of two products, the first an executive summary that is a simple and succinct statement of the results of the mineral-resource appraisal for the use of nongeologists in other government agencies, in the U.S. Congress, and in organizations outside the government who have need of such information, and the second a technical product consisting of data maps and interpretive maps supported by appropriate texts and tables. Because of logistical constraints (primarily time limitations), steps 1-4 may have to be carried out more or less concurrently. Step 1 (compilation of available data), except under extreme circumstances, should largely precede step 4 (field studies). In some instances, simultaneous operation of the first four steps provides a beneficial feedback and interplay of effort.

\section{RECOMMENDATIONS}

Use by the U.S. Geological Survey of the suggestions just outlined for mineral-resource appraisals should provide the advantages of a consistent and systematic process. However, as noted in previous pages, the variations and exceptions in the application of the procedures to CUSMAP quadrangles and wilderness areas in different geologic provinces emphasize the need for flexibility.

The workshop participants recognized that their efforts culminating in this report did not encompass all aspects of resource appraisal at the map scales considered, and they recognized also that many aspects of the procedures proposed can be improved with further knowledge of and experience with mineral 
deposits and mineral-resource appraisals. They recommended that joint studies by government, industry, and academic specialists, such as the December 1979 workshop held in Denver, be continued, and that the U.S. Geological Survey continue to reexamine its methods of mineral-resource appraisal.

The workshop participants also recommended that studies of CUSMAP quadrangles and wilderness areas should provide latitude for scientific investigations beyond the objective of mineralresource appraisals. Funding for research instigated by mineral-resource appraisal projects could come from other sources. Thus, research toward better understanding of geologic environments and processes, and ultimately better success at mineral-resource appraisal, can be fostered and strengthened.

The U.S. Geological Survey invites comments from readers regarding its methods of mineralresource appraisal. Please send comments to the author, Daniel R. Shawe, Mail Stop 905, U.S. Geological Survey, Box 25046, Federal Center, Denver, CO 80225.

\section{APPENDIX A}

\section{Organizing Committee}

Paul A. Bailly, Occidental Minerals Corp., Denver, Colo.

Henry C. Berg, U.S. Geological Survey, Menlo Park, Calif.

Ralph L. Erickson, U.S. Geological Survey, Denver, Colo.

Richard F. Meyer, U.S. Geological Survey, Reston, Va.

Daniel R. Shawe, chairman, U.S. Geological Survey, Denver, Colo.

Donald A. Singer, U.S. Geological Survey, Menlo Park, Calif.

\section{APPENDIX B}

\section{Workshop Participants}

Name

\author{
Allen F. Agnew \\ Frederik P. Agterberg \\ Joseph R. Anzman \\ Roger P. Ashley \\ Paul A. Bailly \\ Paul B. Barton, Jr. \\ Helen M. Beikman \\ Henry C. Berg \\ Byron R. Berger \\ Arthur A. Brant \\ Donald A. Brobst \\ Calvin S. Bromfield \\ Frank C. Canney \\ William R. Cannon \\ Douglas R. Cook \\ Duncan R. Derry \\ John H. DeYoung, Jr. \\ Lawrence J. Drew \\ Gordon P. Eaton \\ Ralph L. Erickson
}

Frank C. Frischknecht

Gus H. Goudarzi

William R. Greenwood

John M. Guilbert

\section{Affiliation}

Library of Congress, Washington, D.C.

GSC, Ottawa, Canada

Houston Oil \& Minerals, Denver

USGS, Menlo Park

Occidental Minerals, Denver

USGS, Reston

USGS, Reston

USGS, Menlo Park

USGS, Denver

Consultant, Tucson

USGS, Reston

USGS, Denver

USGS, Denver

USGS, Reston

Freeport Exploration, Reno

Derry, Michener \& Booth, Toronto

USGS, Reston

USGS, Reston

USGS, Reston

USGS, Denver

USGS, Denver

USGS, Reston

USGS, Denver

University of Arizona, Tucson
Participation

Poplar Bluff 2 (geology)

Hibbing 1 (geostatistics)

Poplar Bluff 2 (geophysics)

Tonopah 1 (geochemistry)

Hibbing 1 (geology)

Hibbing 2 (geology)

Observer

Speaker; Tonopah 1 (geology)

Tonopah 2 (geochemistry)

Speaker; Hibbing 1 (geophysics)

Poplar Bluff 2 (geology)

Tonopah 2 (geology)

Hibbing 1 (geochemistry)

Hibbing 2 (geology)

Tonopah 2 (geology)

Hibbing 2 (geology)

Hibbing 2 (geostatistics)

Speaker; Tonopah 1 (geostatistics)

Tonopah 1 (geophysics)

Speaker; Poplar Bluff 1 (geochemistry)

Hibbing 2 (geophysics)

Observer

Hibbing 1 (geology)

Tonopah 2 (geology) 
Stanley K. Hamilton

William F. Hanna

J. Julian Hemley

Allen V. Heyl

Jean Juilland

William R. Keefer

Stephen E. Kesler

Rodney V. Kirkham

Geoffrey B. Leech

Don R. Mabey

David Menzie

Richard F. Meyer

Leo J. Miller

Ernest L. Ohle

Pierce D. Parker

Jack Phillips

Forrest G. Poole

Walden P. Pratt

William C. Prinz

John W. Rold

Arthur W. Rose

Donald H. Richter

James Rytuba

Donald F. Sangster

Daniel R. Shawe

Paul K. Sims

Donald A. Singer

Norman Stark

Thomas A. Steven

Richard B. Taylor

Ted G. Theodore

William C. J.

van Rensburg

Anne Vickery

Stewart R. Wallace

Stanley H. Ward

John C. Wilson
Amax Exploration, Chesterfield, Mo. USGS, Denver

USGS, Reston

USGS, Denver

USBLM, Denver

USGS, Denver

University of Michigan, Ann Arbor

GSC, Ottawa, Canada

GSC, Ottawa, Canada

USGS, Salt Lake City

USGS, Menlo Park

USGS, Reston

Texasgulf, Golden, Colo.

Consultant, Salt Lake City

Amax Exploration, Denver

Chevron Resources, Denver

USGS, Denver

USGS, Denver

USGS, Reston

Colorado State Geologist, Denver

Pennsylvania State, University Park

USGS, Denver

USGS, Menlo Park

GSC, Ottawa, Canada

USGS, Denver

USGS, Denver

USGS, Menlo Park

USFS, Ogden, Utah

USGS, Denver

USGS, Denver

USGS, Menlo Park

University of Texas, Austin

Colorado Mountain Club, Boulder

Consultant, Denver

University of Utah, Salt Lake City

Anaconda, Denver
Poplar Bluff 2 (geology)

Poplar Bluff 1 (geophysics)

Poplar Bluff 2 (geology)

Poplar Bluff 2 (leader)

Observer

Observer

Poplar Bluff 2 (geology)

Hibbing 2 (geology)

Hibbing 1 (geology)

Tonopah 2 (geophysics)

Poplar Bluff 2 (geostatistics)

Observer

Speaker; Hibbing 1 (geology)

Poplar Bluff 1 (leader)

Poplar Bluff 1 (geology)

Poplar Bluff 1 (geology)

Tonopah 2 (geology)

Poplar Bluff 2 (geology)

Hibbing 2 (geology)

Speaker

Poplar Bluff 2 (geochemistry)

Tonopah 1 (geology)

Tonopah 1 (geology)

Speaker; Hibbing 2 (leader)

Speaker; Tonopah 2 (leader)

Hibbing 1 (leader)

Speaker; Tonopah 2 (geostatistics)

Speaker

Tonopah 2 (geology)

Speaker

Tonopah 1 (geology)

Speaker; Hibbing 1 (geology)

Speaker

Tonopah 1 (geology)

Poplar Bluff 1 (geology)

Tonopah 1 (leader)

GSC Geological Survey of Canada

USBLM U.S. Bureau of Land Management

USFS U.S. Forest Service

USGS U.S. Geological Survey 


\title{
APPENDIX C
}

\author{
Workshop Speakers
}

December 10, 1979

\section{Daniel R. Shawe}

Introduction

The objective of the workshop is to determine the format and the substance of mineral-resource appraisals of CUSMAP quadrangles and wilderness areas. Format considers what steps need to be taken in collecting data, analyzing data, and finally in generating the resource appraisal. Substance considers how the resource information should be presented: statements of qualitative value; semiquantitative assessments such as small, moderate, large, low-grade, high-grade; or as subjective statistical probabilities.

\section{Norman Stark}

The U.S. Forest Service's view of mineral-resource appraisals

The Forest Service, in order to make its determinations on land use for wilderness and RARE II lands, requires easily understandable information presented in simple maps, tables, and texts. Mineral potential should be rated as specifically as possible, giving numerical data. Data presented should include areas of favorable geology, locations of mines and deposits, what minerals are present, their critical nature, their economic value, when and how they are to be mined, and what area is needed to mine them.

\section{Anne Vickery}

The environmentalists' view of mineral-resource appraisals

The primary point of view of environmentalists is that, in wilderness areas, there should be no exploration for mineral resources, although surface geologic mapping and map interpretations are appropriate. In lands reserved for wilderness, the most important resource values are untouched or natural ecological and biological systems, water and air sheds, and recreational use. Improved communication between environmentalists and mineral-resource appraisers is desirable.

\section{John W. Rold}

\section{Requirements of mineral-resource appraisal presentations}

Simple maps are the most effective way to show evaluations. The appraisals must be geologically and technically accurate, they should be conducted with a mineral-exploration approach, the results must be defensible, the data must be presented in an understandable manner, and the data must be timely.

\section{Leo J. Miller}

The mining industry's outlook on mineral-resource appraisals

Previously published U.S. Geological Survey reports on mineral-resource appraisals are difficult for bureaucrats to understand. In general, appraisals of areas have not been enhanced by the use of geochemical and geophysical data. The most important factors to consider in future reports are these: (1) An understanding of the total geologic environment is fundamental to mineral-resource appraisals, and (2) geologic environments favorable for the occurrence of mineral deposits are essential to our society and civilization.

\section{William C. J. van Rensberg}

A review of the philosophy of mineral resources

The two basic sources of wealth are agriculture and mining. There are two types of mineral commodities in the United States, those that are not adequate (manganese, nickel, 
chromium, and so forth), and those that could be adequate (copper, molybdenum, and so forth). Many commodities are becoming more difficult to obtain overseas and stockpiles in some strategic commodities are inadequate. Distinction should be made between the strategic and economic value of resources, such as resources of chromium in the Stillwater Complex.

Resources are made; they don't simply exist; and they are made through progressive steps of exploration. Because of the uncertainty of resources, we can hardly pass up any opportunity to obtain them. Evaluations of resources need to take into consideration lead times and delays resulting from exploration, regulations, and other factors.

The definition of "resources" to include "undiscovered resources" (for example, the McKelvey diagram) is a recent development. Great care must be applied in attaching numbers to unknown resources defined as "hypothetical" and "speculative."

\section{Richard B. Taylor}

The realm of the possible in U.S. Geological Survey mineral-resource appraisal

Funding and staffing levels for the mineral appraisal programs of the U.S. Geological Survey require that most of the project activities be regional in scope. Under the CUSMAP program, 1:250,000-scale geologic compilations, aeromagnetic and gravity surveys, and stream-sediment geochemical surveys form the core of the program. Similar activities at about 1:50,000 scale are characteristic of appraisal projects of wilderness areas. Detailed studies to characterize deposit types and topical studies to solve geologic problems, including isotopic studies, and more detailed geophysical and geochemical surveys can and will be undertaken, but the level of support for detailed work is limited. As interpretation of the regional data depends upon detailed data synthesized into occurrence models, a limited number of these detailed studies in the economic geology of ore deposits will be a regular part of the appraisal programs.

\section{Arthur A. Brant}

Factors in mineral-resource appraisal

The U.S. Geological Survey should make mineral appraisals, not resource appraisals. A committee composed of U.S. Geological Survey and mining industry representatives to consult on the problems of mineral appraisals would be valuable.

\section{Ralph L. Erickson}

Role of geochemistry in mineral-resource appraisal

The role of geochemistry in mineral-resource appraisal depends upon the existing geologic knowledge of the area being assessed. Geochemistry can and should be used to help (1) recognize and define broad geochemical provinces, (2) establish zoning patterns of mineralizing systems and mineral districts, and (3) outline favorable ground for mineral discovery within the broad system or district. In this framework, concepts can then be tested about recognition and understanding of mineralizing systems, potential areas for concealed mineral deposits, and new and conventional environments of ore deposition.

Successful use of geochemistry in mineral-resource appraisal requires a knowledge of the geochemical cycle of elements, normal crustal abundances and distribution in relation to rock type, diagnostic suites of elements that characterize certain types of deposits, metal endowment and enrichment, and attributes of different geochemical sample media and different analytical methods.

\section{Lawrence J. Drew}

Subjective-experience judgment in mineral-resource appraisal

A group of experienced mineral-resource specialists can, on the basis of their knowledge of the environments of ore deposits, make individual subjective assessments of possible resources within specific areas. The range of the individual assessments considered together provides a basis for establishing probability for the occurrence of the resources. 


\section{Donald F. Sangster}

Metallogeny in mineral-resource appraisal

Metallogeny is similar in definition to ecology: the interrelationships of mineral deposits and their environments. Recognition of favorable environments provides the key to resource appraisal. Evaluations must be made by experts using subjective judgment rather than by machines that have been fed data. Estimates of resources can be presented as ranges of tonnages and grades.

\section{Donald A. Singer}

Review of geostatistical methodology of mineral-resource appraisal with emphasis on the U.S. Geological Survey's Alaska program

Many statistical methods are used for mineral-resource assessment either by extrapolation or by analogy. Extrapolation uses such methods as time-rate, crustal-abundance, and cumulative tonnage-versus-grade. Analogy uses such methods as simple subjective, complex subjective, Bayesian, frequency, trend, geometric probability, multiple regression, discriminant, modified component, multivariate logistic, cluster analysis, "pattern recognition," and simulation. The type of appraisal product needed influences selection of method of assessment.

\section{Henry C. Berg}

The U.S. Geological Survey's Alaska mineral-resource appraisal program

The Alaska Mineral Resource Assessment Program (AMRAP) is a statewide investigation of mineral potential whose objective is to show on a map areas that have metallic mineral potential and areas that do not. Metals that might be found and types of deposits in which they might occur are identified where possible. If enough data are available, a quantitative-probabilistic estimate of undiscovered resources contained in those mineral deposits is presented.

AMRAP is a long-term, systematic program in which the basic land unit studied is the $1: 250,000$-scale quadrangle (there are 153 in Alaska). Much field and laboratory work is involved, and the results are published as a folio of maps that usually includes the following: (1) a geologic map, (2) a suite of geochemical maps and a computer printout of all analyses, (3) an aeromagnetic map based on flightlines at 1-mi $(1.6-\mathrm{km})$ spacing, (4) a map of known deposits and occurrences, (5) a map based on interpretations of satellite images, and (6) a resource-assessment map. A pamphlet describing the salient results of the investigations accompanies the maps.

Such a study of a quadrangle requires approximately 3 years to complete the field and laboratory work and another year to publish the results. Each quadrangle involves at least 30 man years of work. Since the program began in 1974, resource assessments have been completed in 22 quadrangles. Field and laboratory investigations currently are underway in five quadrangles. 
